\title{
Documenting Freedom From Disease and Re-Establishing a Free Status After a Breakdown Rabies
}

\author{
By Liisa Sihvonen
}

National Veterinary and Food Research Institute, Department of Virology and Epidemiology, P.O.Box 368, SF00231 Helsinki, Finland.

\begin{abstract}
Rabies reappeared in Finland in the spring of 1988 after a 29-year absence. This time rabies occurred in sylvatic form and the major species involved was the raccoon dog. During the outbreak 1988-89 66 animals were diagnosed rabid. Vaccination of cats, cattle and horses was strongly recommended and vaccination of dogs was compulsory in the outbreak area. A field trial was started on oral immunisation of raccoon dogs and foxes against rabies using baits containing rabies vaccine strain. The outbreak area and a wide buffer zone were baited three times. Finland was declared free of rabies again in 1991. Oral vaccination campaign with vaccine baits has been organised along the southeastern border once a year since the beginning of 90s. Continuous surveillance and epidemiological screening is necessary to detect any new outbreaks of rabies at an early stage.
\end{abstract}

\section{Rabies virus}

The virus of rabies is a member of the genus Lyssavirus. Rabies virus can infect all warmblooded animals, and in nearly all instances the infection ends in death. Rabies virus is not stable in the environment and in usual circumstances is only a risk when transmitted by the bite or scratch of a rabid animal. In bat caves, however, where amounts of virus may be very high, it can be transmitted via aerosol.

\section{Earlier dog rabies outbreaks before 1959}

Finland was first declared free of rabies in 1936. Vaccination of dog population had started in 1929. In the years 1940-42 and 1952-59 new cases were recorded in the south-eastern border areas. These outbreaks were controlled by restricting the movements of dogs and cats, shooting stray animals and vaccinating the dog population. During the years 1910-59, a total of 2300 animals were recorded as rabid, including only one wolf and two foxes. These figures in-

dicate the absence of an established reservoir of sylvatic rabies.

\section{Sylvatic rabies outbreak in 1988-1989}

In early April 1988, one fox and one dog were diagnosed rabid west of the river Kymi, about $100 \mathrm{~km}$ west of the south-eastern national border. This time rabies occurred in sylvatic form. The major species involved was raccoon dog (Nyctereutes procyonoides) and not red fox (Vulpes vulpes). The first raccoon dogs had been observed in Finland in the 1930's, but a significant population was established during the 1970s and 1980s (Helle \& Kauhala 1987). The calculated population density of the raccoon dog in the outbreak area was approximately 0.3 animal $/ \mathrm{km}^{2}$ in the spring and 1.0 an$\mathrm{imal} / \mathrm{km}^{2}$ in the autumn. The population density of the red fox was about 0.15 and 0.3 animals $/ \mathrm{km}^{2}$, respectively.

During 1988 and 1989, 3015 animals from the 
whole country were examined for rabies. During the outbreak 66 animals were diagnosed rabid: 48 raccoon dogs, 12 foxes, 2 badgers, 2 cats, one dog and one young bull (Nyberg et al. 1992). No cases were recorded within $60 \mathrm{~km}$ of the national eastern border in spite of intensive sampling. Most probable hypothesis is that the infection was brought in by wolves migrating on the ice along the coast. Spread of rabies by land through an animal to animal chain from behind the south-eastern border seems unlikely. The third and least plausible hypothesis is that rabies could have entered Finland with raccoon dogs hiding in timber boxcars from the USSR. The rabies virus was shown by monoclonal antibodies to be an arctic-type strain and different from the one occurring in foxes in continental Europe (Nyberg et al. 1992, Kulonen \& Boldina 1993). Arctic rabies has been reported from Estonia, the Leningrad area and Kola peninsula (Selimov et al. 1990).

\section{Rabies control and re-establishing rabies free status}

The most important natural or artificial obstacles to the spread of rabies are lakes, high mountain ranges, large and rapidly flowing rivers, major cities and motorways lined with game-proof fences (Kappler et al. 1988). The importance of lakes and the Kymi river in preventing and directing the expansion of the epidemic was obvious also in Finland.

The raccoon dog sleeps for a variable time during winter. This phenomenon might be of importance in the epidemiology of rabies, because the contact rate might fall to the level at which the disease disappears.

In the outbreak area, vaccination of dogs was compulsory and voluntary vaccination of cats, cattle and horses was recommended. In the country as a whole, vaccination of dogs used for hunting and those put on show became compulsory and voluntary vaccination of pet dogs and cats was strongly recommended. Promising results had been obtained from field trials on oral immunisation of foxes against rabies in Central Europe (Wandler 1988). The rabies baits are evenly distributed in the terrain, at least $15 / \mathrm{km}^{2}$ if spread on the ground by e.g. hunters and at least $20 / \mathrm{km}^{2}$ if by air.

In September 1988, a field trial was started on oral immunisation of raccoon dogs and foxes against rabies. Rabies baits containing capsules with SAD B19 vaccine strain were distributed over the outbreak area. Throughout the following winter raccoon dogs and foxes from the campaign area were examined serologically for antibodies against rabies. $72 \%$ of raccoon dogs and $66 \%$ of the foxes had antibody titres indicating immunity (Nyberg et al. 1992). In April 1989 a second bait distribution campaign was carried out and baits were distributed over an area, including the first campaign area and a wide buffer zone surrounding it. In the fall of 1989 the estimated infection area was baited a third time. In June 1990 the part of it not baited in 1988 was baited a third time. A surveillance of vaccination area was continued. The last case was recorded in February 1989. The outbreak area in south-eastern Finland was estimated to cover $1700 \mathrm{~km}^{2}$ and the bait vaccination area covered about $8000 \mathrm{~km}^{2}$.

A country will be declared free of rabies after 2 years of epidemiological surveillance without any reported cases of rabies in either wildlife or domestic animals. Finland was declared free of rabies again in 1991.

\section{Documenting freedom from rabies}

The situation in Russia in relation to rabies is at the time being unclear. However, despite of the sparse information available, it is clear that the unprotected area on the Russian side poses a risk for rabies spreading from that area into Finland, taking also into account the unfavourable rabies situation in Baltic countries. Finland tries 
to minimise the risk of rabies being re-introduced. To combat this risk a $20 \mathrm{~km}$ cordon sanitaire along the south-eastern border has been spread with vaccine baits once a year since the beginning of 90s. Raccoon dogs and foxes are regularly examined serologically for antibodies against rabies to monitor the efficacy of bait vaccination. The results of these studies have been in line with earlier studies reported by $\mathrm{Ny}$ berg et al. (1992).

Crucial for the survival of rabies is that the virus is transmitted by an infected animal to enough susceptible animals during the short period of virus excretion. The rate of infectious contacts is density-dependent. Rabies transmission ceases when the population density drops below a certain level, or when herd immunity reaches the (density-dependent) threshold. Raccoon dog and fox population reduction is an important part of prevention of an epidemic in wildlife. The populations of raccoon dogs and foxes in Finland are controlled by hunting.

Continuous surveillance and epidemiological screening is necessary to detect any new outbreaks of rabies at an early stage. During 1997 and 1998, 451 and 512 animals, respectively, were examined for rabies virus.

Dog-mediated rabies prevention is best accomplished by control of imported dogs and cats. Dogs and cats coming from WHO recognised rabies-free countries are not considered to pose a risk when imported directly to Finland. All other imported dogs and cats must be properly vaccinated with the killed rabies vaccine produced in cultured cells. The dogs and cats must show no signs of disease on day of dispatch.

\section{References}

Helle E, Kauhala K: Supikoiran leviämishistoria ja kantojen nykytila. (Distribution history and present status of the raccoon dog in Finland). Suomen Riista 1987, 34, 7-21.

Kappler A, Wandeler AI, Capt S: Ten years of rabies control by oral vaccination of foxes in Switzerland. In: Pastoret P-P, Brochier B, Thomas I, Blancou J, (eds):EUR 11439-Vaccination to control rabies in foxes. Office for Official Publication of the European Communities, Luxembourg, 1988, pp. 55-60.

Kulonen K, Boldina I: Differentiation of two rabies strains in Estonia with reference to recent Finnish isolates. J. wildl. Dis. 1993, 29, 209-213.

Nyberg M, Kulonen K, Neuvonen E, Ek-Kommonen $C$, Nuorgam M, Westerling B: An epidemic of sylvatic rabies in Finland - Descriptive epidemiology and results of oral vaccination. Acta vet. Scand. 1992, 33, 43-57.

Selimov MA, Botvinkin AD, Khozinski VV, Kyueva EV, King A, Petrenko LG, Dolzhanov PB, Korneeva SA, Barinova LI, Korzhenkova A: Lyssavirus characterisation with monoclonal antibodies on strains of certain regions of the USSR. Rabies Bull. Eur. 1990, 14, 8-9.

Wandler AI: Control of wildlife rabies: Europe. In Rabies: Campbell JB, Charlton KM, (eds.): Developments in Veterinary Virology. Kluwer Academic Publishers, Boston/Dordrecht/London, 1988, pp. 365-380. 